

\title{
THE EFFECT OF ENTREPRENEURIAL COMPETENCE ON PERCEIVED BEHAVIORAL CONTROL AND PERSPECTIVE OF GENDER
}

\author{
Sanna Joensuu-Salo ${ }^{1}$, Anmari Viljamaa ${ }^{2}$, Elina Varamäki ${ }^{3}$ \\ ${ }^{1}$ Seinäjoki University of Applied Sciences (FINLAND) \\ ${ }^{2}$ Seinäjoki University of Applied Sciences (FINLAND) \\ ${ }^{3}$ Seinäjoki University of Applied Sciences (FINLAND)
}

\begin{abstract}
Higher education institutes are seeking ways to support entrepreneurship and entrepreneurial skills of students by developing entrepreneurial education. The development of the entrepreneurial capacity in Europe is one of the key policy objectives for the EU. For reaching this goal, the EntreComp framework was developed in order to raise consensus between different stakeholders by proposing a shared definition of entrepreneurship as a competence. The objectives of this paper is to examine the relationship between entrepreneurial competence and perceived behavioral control. In addition, the objective is to investigate the effect of gender on this relationship. Perceived behavioural control is one of the antecedents of entrepreneurial intentions [1].

The data was gathered from Finnish higher education students in fall 2019 by a web-based survey. Altogether 501 answers were received of which 49 percent were from women and 51 percent were from men. Students represented various study fields. The measurement instrument has been developed in Finland, and piloted in several higher education institutes. The measurement of entrepreneurial competence was based on European Commission's Entre Comp Framework. The other parts measured the concepts related to Theory of Planned Behaviour in the context of entrepreneurship. In this study, the concept of perceived behavioural control was used. The scales of entrepreneurial competence (scales for interconnected competence areas 'Ideas and opportunities', 'Resources' and 'Into action') and perceived behavioural control had acceptable reliability ratios (Cronbach's alphas ranging from $0.76-0.81$ ). Linear regression analysis was used to test a model in which different competence areas explained perceived behavioural control. This model was tested separately for male and female students.
\end{abstract}

Results show that for women, the model explains 25 percent of the variance in perceived behavioural control. The most important factor in the model is the competence area "resources" $\left(\beta=0.33^{* *}\right)$. However, other competence areas are not statistically significant in the model. For men, the results differ. The whole model explains 22 percent of the variance in perceived behavioural control. The most important factor in the model is the competence area "into action" $\left(\beta=0.23^{*}\right)$. Other areas do not explain perceived behavioral control significantly. This study shows that entrepreneurial competence has an effect on perceived behavioural control. Earlier research has demonstrated the importance of perceived behavioural control explaining both entrepreneurial intention and behaviour. Thus, it is important to develop students' entrepreneurial competence in different areas if we want to boost entrepreneurship. The competence area "resources" is more important for women, while the competence area "into action" is more important for men. In entrepreneurship education this means that women should be especially supported in developing their competence in believing themselves, gathering needed resources and understanding financial issues. For men, the most important factors are the competences related to prioritizing, making decisions in uncertain situation, collaborating and reflecting.

Keywords: entrepreneurial competence, perceived behavioural control, gender, higher education.

\section{INTRODUCTION}

Entrepreneurship is an important factor in society creating well-being and new jobs. Higher education institutes are seeking ways to support entrepreneurship and entrepreneurial skills of students by developing entrepreneurial education. In addition, European commission has recognized entrepreneurship as a key competence necessary for a knowledge-based society [2]. The 
development of the entrepreneurial capacity in Europe is one of the key policy objectives for the EU. For reaching this goal, the EntreComp framework was developed in order to raise consensus between different stakeholders by proposing a shared definition of entrepreneurship as a competence [2]. It has three interrelated and interconnected competence areas of "ideas and opportunities", "resources" and "into action". Entrepreneurial competence has been recognized to be very important for future business practitioners [3], [4]. Hence, it could be assumed that entrepreneurial competence is somehow related to individual's evaluation of his/her ability to act as an entrepreneur.

When examining individual's intention to become an entrepreneur, the most used model is Ajzen's [1] Theory of Planned Behavior. It assumes that intention precedes behavior and intention is explained by three different factors: attitudes towards the behavior, perceived behavioral control and subjective norm. Regarding entrepreneurship, subjective norm refers to the pressure of most important people experienced by the individual if he/she would become an entrepreneur. Perceived behavioral control in turn refers to individual's assessment how difficult or easy it would be for him/her to start a business and act as an entrepreneur [1]. It makes sense, that perceived behavioral control is linked with entrepreneurial competence. However, most of the research concerning entrepreneurial competences is concentrated in explaining how these competences lead to success or performance in a job, or to business performance and growth [5]. Previous literature has not examined the relationship between entrepreneurial competence and perceived behavioral control. This study shows that these concepts are related, and gives implications for entrepreneurship education.

In entrepreneurship, gender has a significant role. Men start businesses more likely than female both during studies and after graduation, and men have higher entrepreneurial intentions [6], [7]. In addition, female score lower on entrepreneurial self-efficacy [8], and entrepreneurial pedagogy has different effects on male and female students [9]. This suggests that there may be also gender differences regarding the interplay of entrepreneurial competences and perceived behavioral control.

This study is implemented in the context of higher education. It has two objectives: 1) examine the effect of entrepreneurial competence on perceived behavioral control with higher education students, and 2) examine gender differences in the impact of entrepreneurial competence on perceived behavioral control. The hypothesized model will be tested with linear regression analysis. For examining gender differences, this model will be tested separately for men and women. The data was gathered from Finnish higher education students studying their first year at the university.

\section{THEORETICAL FRAMEWORK}

Entrepreneurial competence has been defined in many ways in previous research. Man, Lau and Chan [10] state that entrepreneurial competences can be seen as higher level features that represent entrepreneurs' capacities to succeed in the workplace. Chandler and Jansen [11] in turn, argue that entrepreneurs need managerial, technical/functional and entrepreneurial competences to be successful. Mitchelmore and Rowley [5] summarize that entrepreneurial competencies have been identified as a specific group of competencies relevant to the exercise of successful entrepreneurship. However, Ferreras-Garcia, Hernández-Lara and Serradell-López [12] point out that despite of earlier research work on entrepreneurial skills, it is still difficult to find a precise identification of entrepreneurial competences.

The discussion about entrepreneurial competence was recognized to be important for the development of entrepreneurial capacity of European citizens and organizations by the European Commission. On the initiative of European Commission, an EntreComp framework was developed proposing a shared definition of entrepreneurship as a competence [2]. The aim was to raise consensus among all stakeholders. The EntreComp framework was developed through a mixedmethods approach and it consists of three interrelated and interconnected competence areas of "Ideas and opportunities", "Resources", and "Into action". Each of the separate areas is made up of five competences. These together will represent the whole entrepreneurial competence.

EntreComp framework defines sense of initiative and entrepreneurship as the capacity to turn ideas into action, ideas that generate value for someone other than oneself [2]. It is seen as a transversal key competence, which every citizen needs for personal fulfilment and development, active citizenship, social inclusion and employment in the knowledge society. It focuses on value creation in the private, public and third sectors, and is seen as competence that applies to all spheres of life. 
Figure 1 presents the EntreComp framework as a pie chart. Blue colour refers to the competences in the "Ideas and opportunities", orange for "Resources", and green for "Into Action". The slices embrace all the 15 competences [2).

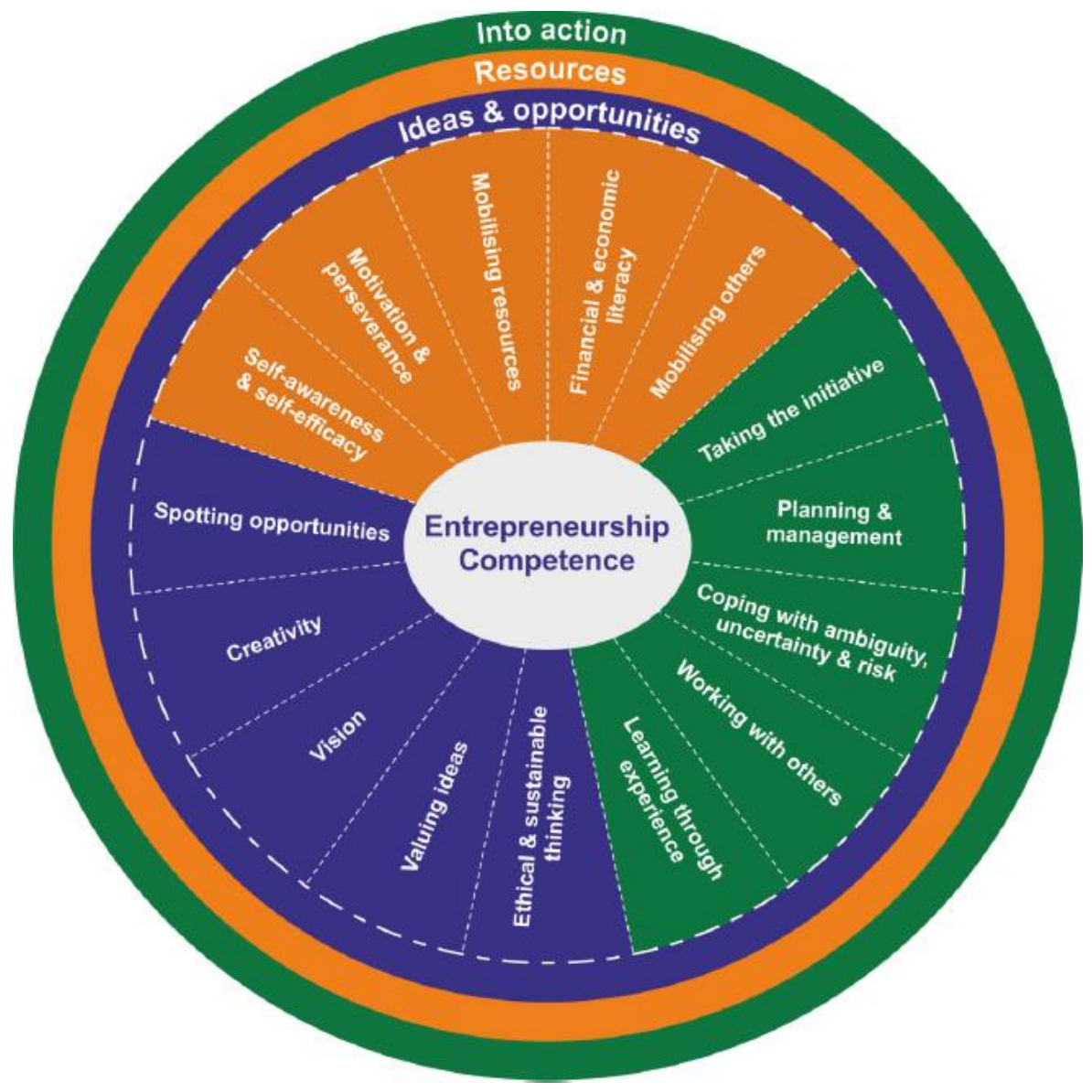

Figure 1. EntreComp Framework [2].

For the area of "Ideas and opportunities" there are competencies related to spotting opportunities, creativity, vision, valuing ideas, and ethical \& sustainable thinking. For the area of "Resources" the competences refer to self-awareness \& self-efficacy, motivation \& perseverance, mobilizing resources, financial \& economic literacy, and mobilizing others. For the area of "Into action" the competences relate to taking the initiative, planning \& management, coping with ambiguity, uncertainty \& risk, working with others, and learning through experience.

The EntreComp Framework is quite new and there is a lack of research testing it in various situations. However, previous literature on entrepreneurial competences support the idea, that it may be related to entrepreneurial behavior in many ways. One important factor when examining entrepreneurial behavior is entrepreneurial intention and its antecedents. The most used model in entrepreneurial intention research is the Theory of Planned Behavior (TPB) developed by Ajzen [1]. TPB is based on the theory of Reasoned Action [13], [14], which is designed to predict volitional behaviors. Ajzen [1] states that a person's intention to perform (or not to perform) a behavior is the immediate determinant of that action. Intention itself is explained by three determinants: attitude, subjective norm and perceived behavioral control. Attitude refers to the individual's positive or negative evaluation of performing the behavior, and subjective norm to the person's perception of the social pressures put on $\mathrm{him} / \mathrm{her}$ to perform or not perform the behavior in question [1]. TPB differs from the original Theory of Reasoned action by adding a third variable to the model: Perceived behavioral control. Ajzen [1] states that "The importance of actual behavioral control is self evident: The resources and opportunities available to a person must to some extent dictate the likelihood of behavioral achievement. Of greater 
psychological interest than actual control, however, is the perception of behavioral control and is impact on intentions and actions." As such, perceived behavioral control refers to individual's perception of the ease or difficulty of performing the given behavior.

It is reasonable to assume, that this perception of the resources and opportunities is linked to entrepreneurial competence of the individual. However, there is a lack in literature examining this relationship. Farooq et al. [15] argues that a high level of entrepreneurial skills will positively influence the personal attitude towards entrepreneurship, subjective norm and perceived behavioral control. In another study, Farooq [16] showed that entrepreneurial skills had a direct and positive influence on perceived behavioral control. Hence, this study hypothesizes a positive relationship between entrepreneurial competence and perceived behavioral control.

This study has a gender perspective. Gender has proven to be a significant factor explaining both entrepreneurial intentions and behavior [9], [17], [18], [19]. Women have less desire to start new businesses than men, and they score lower on entrepreneurial self-efficacy than their male counterparts [20]. Interestingly, Yordanova and Tarrazon [6] found that gender effect on entrepreneurial intentions was fully mediated by perceived behavioural control. Hence, this study hypothesizes a gender effect in the impact of entrepreneurial competence on perceived behavioral control. Figure 2 presents the conceptual model of the study to be tested.

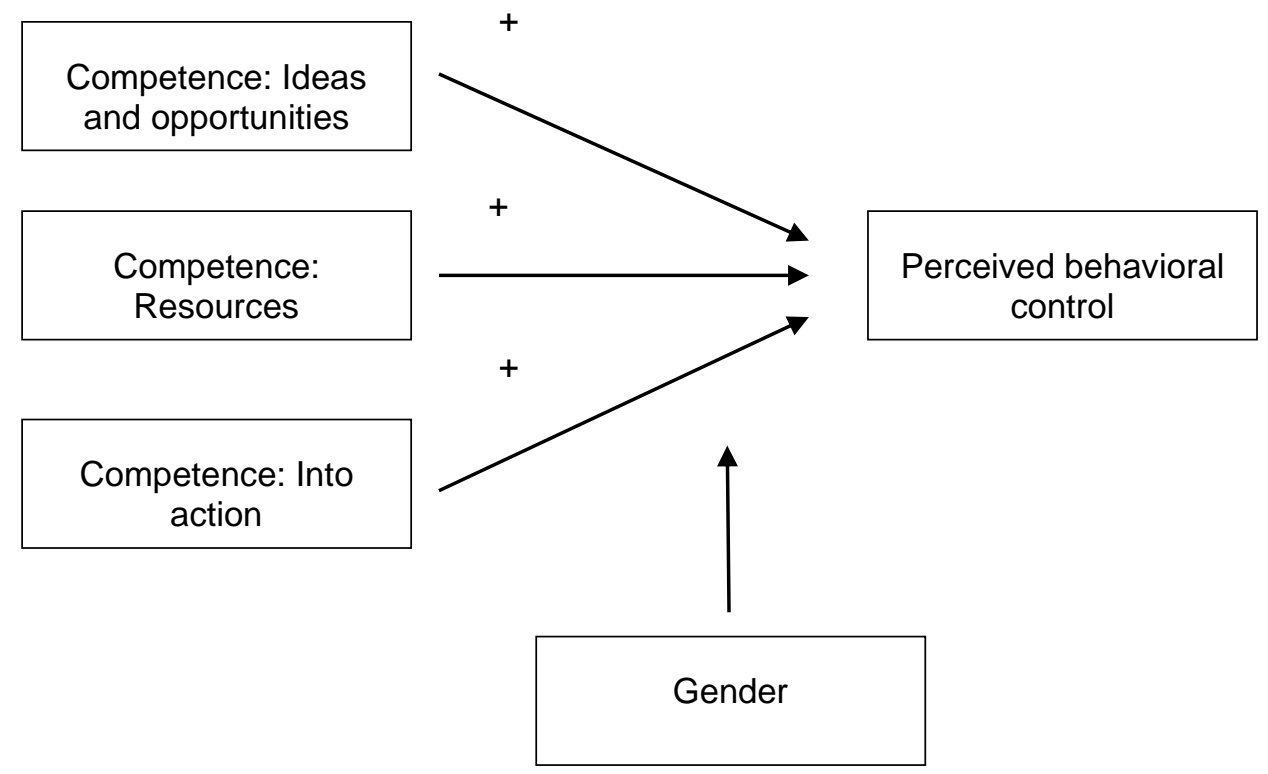

Figure 2. Conceptual model for the study.

The model proposes four hypotheses:

H1: Competence area of ideas and opportunities has a positive influence on perceived behavioral control.

H2: Competence area of resources has a positive influence on perceived behavioral control.

H3: Competence area of into action has a positive influence on perceived behavioral control.

$\mathrm{H} 4$ : The relationships in the model are different between genders.

\section{METHODOLOGY}

Data for this research was gathered from Finnish higher education students studying in their first year at Seinäjoki University of Applied Sciences. The data was collected using a self-administered questionnaire in fall 2019. There are altogether 501 answers in the data, of which 49 percent are from women and 51 from men. The mean age of the respondents is 24 years. Students represent different 
study fields. 37 percent of the students study in the field of Technology, Communications and Transport, 23 percent in Social services, Health and Sports, 18 percent in the field of Business and Administration, 7 percent in Tourism, Catering and Domestic Services, 9 percent in Natural Sources and the Environment, and 6 percent in Culture.

The instrument used in the study has been developed and piloted in Finland. The scale measuring perceived behavioral control is based in Ajzen's (1991) Theory of Planned behavior and the scale used by Kolvereid [21]. It was measured with five items (see Appendix 1) and the reliability was acceptable (Cronbach's alpha 0.77 ) based on Nunnally's [22] recommendations.

The measurement of entrepreneurial competence was developed for this research based on the EntreComp Framework [2]. The hints for understanding different competences were used in forming the items. All the scales are presented in Appendix 1. The competence area of ideas and opportunities was measured with five items. Cronbach's alpha demonstrated good reliability for the scale $(0.81)$. The competence area of resources was measured with five items. The reliability of the scale was acceptable (Cronbach's alpha 0.76). The competence area into action was measured with five items. Cronbach's alpha for the scale was 0.79 indicating acceptable reliability ratio.

We tested the possible effects of common method variance for the variables collected using Harman's one factor test [23]. If common method variance was a serious problem in the study, we would expect a single factor to emerge from a factor analysis or one general factor to account for most of the covariances in the independent and dependent variables [24]. All the items used to create the main variables, a total of 20 items, were factor analysed using principal axis factoring where the unrotated factor solution was examined, as recommended by Podsakoff et al. [25]. Kaiser's criterion for retention of factors was followed. The sample size seemed to be large enough for the factor analysis, at least based on the Kaiser-Meyer-Olkin measure of sampling adequacy $(\mathrm{KMO}=0.93)$.

Factor analytic results indicated the existence of three factors with eigenvalues greater than 1.0. These factors explained 48 percent of the variance among the 20 items, and the first factor accounted for 22 percent of the variance. Since several factors, as opposed to one single factor, were identified and since the first factor did not account for the majority of the variance, a substantial amount of common method variance does not appear to be present.

For testing the conceptual model, linear regression analysis was used. The model was tested separately for men and women to see possible differences in the whole model.

\section{RESULTS}

Table 1 presents the results of the linear regression analysis for explaining perceived behavioural control. Model A presents the coefficients for women students and Model B for men students. As results show, for both genders, the model explains significantly perceived behavioural control. Hence, entrepreneurial competence is linked to individual's perception of his/her capabilities in performing as an entrepreneur. For women students the whole model explains 25 percent of the variance in perceived behavioural control (F-statistics $27.476^{\star * \star}$ ), and for men students 22 percent (F-statistics $\left.24.323^{* * *}\right)$.

Interestingly, the significant variables in the models vary between genders. For women students only significant variable in the model is the competence area resources $\left(\beta .326^{* *}\right)$. For men students, the results differ. In their model only the resource area into action $\left(\beta .232^{*}\right)$ explains perceived behavioural control significantly. This means that with women, the sub-competences of self-awareness \& selfefficacy, motivation and perseverance, mobilising resources, financial \& economic literacy, and mobilising others explain significantly perceived behavioural control. In contrast, the sub-competences of taking the initiative, planning \& management, coping with ambiguity, uncertainty \& risk, working with others, and learning through experience explain significantly the perceived behavioural control of men. 
Table 1. Results for the linear regression analysis.

\begin{tabular}{l|c|c}
\hline \hline & Model A (women) & Model B (men) \\
\hline Constant & 1.137 & 1.284 \\
& $(.349)$ & $(.368)$ \\
\hline Ideas and opportunities & .016 & .130 \\
& $(.116)$ & $(.114)$ \\
& $\beta .013$ & $\beta .110$ \\
\hline Resources & $.360^{* *}$ & .205 \\
& $(.118)$ & $(.116)$ \\
& $\beta .326$ & $\beta .170$ \\
\hline Into Action & .208 & $.276^{*}$ \\
& $(.132)$ & $(.129)$ \\
\hline R-squared & $\beta .186$ & $\beta .232$ \\
\hline Adjusted R-squared & .254 & .227 \\
\hline F-statistics & .245 & .217 \\
\hline
\end{tabular}

Standard errors are reported in parentheses.

${ }^{*},{ }^{* *},{ }^{* * *}$ indicate significance at the $90 \%, 95 \%$, and $99 \%$ level respectively.

Figure 3 present the model for women students and Figure 4 for men students.

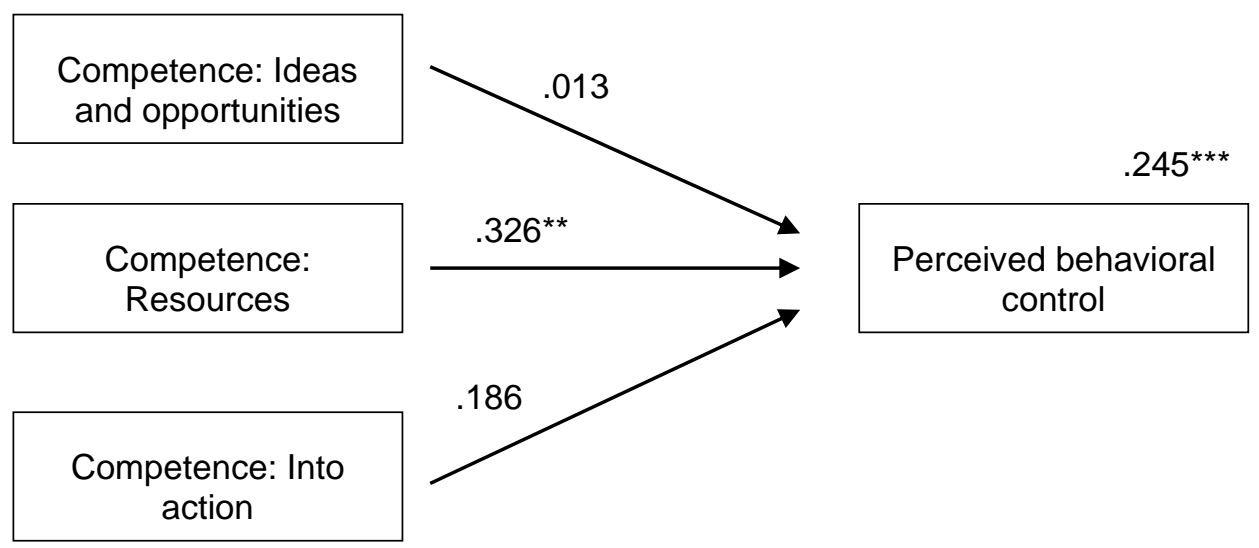

Figure 3. Linear regression model for women. 


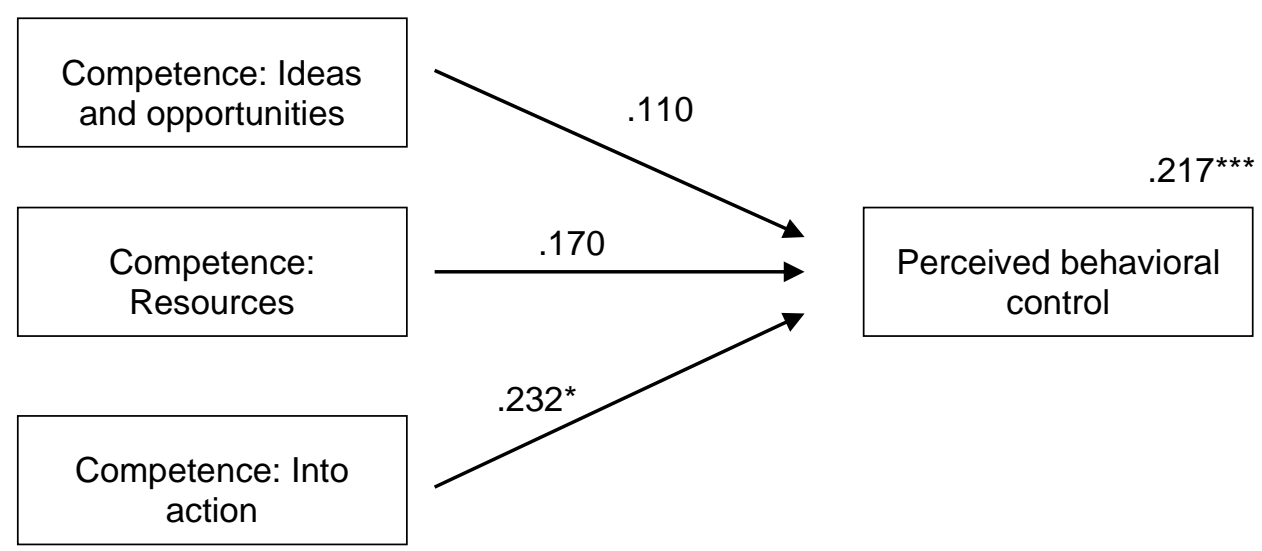

Figure 4. Linear regression model for men.

\section{CONCLUSIONS}

The first objective of this study was to examine the effect of entrepreneurial competence on perceived behavioral control with higher education students. Results show that entrepreneurial competence has a link with perceived behavioral control. Individuals, who have higher entrepreneurial competence, have higher perceived behavioral control. Hence, they feel that they would succeed in entrepreneurial career if they wanted to. This in line with previous argument of Mitchelmore and Rowley [5], who stated that entrepreneurial competencies are relevant to the exercise of successful entrepreneurship. Likewise, individuals, who perceive themselves as having entrepreneurial competencies, also believe they would manage as entrepreneurs.

The second objective of this research was to examine gender differences in the impact of entrepreneurial competence on perceived behavioral control. Results verify that there are differences between genders. For both genders, entrepreneurial competence explains significantly perceived behavioral control. However, for women, the competence area of resources is more important factor in explaining PBC. For men, the competence area of into action is a central factor explaining perceived behavioral control. Previous research has shown that women score lower on entrepreneurial selfefficacy compared to men [20]. Self-efficacy is one of the sub-competences in the competence area of resources. Results implicate that with women, this is a central factor if we want to boost women entrepreneurship. By improving women's self-efficacy and other resource related sub-competences, we can influence positively on their perceived behavioral control. This in turn has an effect on entrepreneurial intentions and finally on entrepreneurial behavior.

These results have implications on entrepreneurship education. With men, it is important to increase their ability to initiate, plan, manage, cope with risk, work with others and learn through experience. Men would benefit from teamwork, in which they could obtain cooperation skills. In addition, reflection is important - using i.e. learning diaries and discussions about their experiences would be beneficial. With women, the most important thing is to have an effect on their self-awareness and self-efficacy, motivation and ability to understand financial issues. Also ability to mobilize others is important. For improving women's self-efficacy, entrepreneurial education should provide entrepreneurial experiences in which women would succeed. This could include i.e. project works and working with real entrepreneurs. Women could also benefit from self-reflections as a rehearsals and discussion about motivational issues.

This study has some limitations. The data was gathered only from one country and it is crosssectional. The results need verification in international context. In future research, longitudinal studies would bring more light how entrepreneurial education can affect entrepreneurial competencies of men and women. 


\section{REFERENCES}

[1] I. Ajzen, "The Theory of Planned Behavior," Organizational Behavior and Human Decision Processes, vol. 50, no. 2, pp. 179-211, 1991.

[2] M. Bacigalupo, P. Kampylis, Y. Punie and G.Van den Brande, EntreComp: The Entrepreneurship Competence Framework. Luxembourg: Publication Office of the European Union, 2016.

[3] J.C. Sánchez, "University training for entrepreneurial competencies: its impact on intention of venture creation," International Entrepreneurship Management Journal, vol. 7, no. 2, pp. 239254, 2011.

[4] V. P. Taatila, "Learning entrepreneurship in higher education," Education+Training, vol. 52, no. 1, pp. 48-61, 2010.

[5] S. Mitchelmore and J. Rowley, "Entrepreneurial competencies: a literature review and development agenda," International Journal of Entrepreneurial Behavior \& Resesarch, vol. 16, no. 2, pp. 92-111, 2010.

[6] D. Yordanova and M-A. Tarrazon, "Gender differences in entrepreneurial intentions: evidence from Bulgaria," Journal of Developmental Entrepreneurship, vol. 15, no. 3, pp. 245-261, 2010.

[7] E. Varamäki, S. Joensuu, E. Tornikoski and A. Viljamaa, "The development of entrepreneurial potential among higher education students," Journal of Small Business and Enterprise Development, vol. 22, no. 3, pp. 563-589, 2015.

[8] European Commission, Effects and impact of entrepreneurship programmes in higher education. DG for Enterprise and Industry. Brussels: Entrepreneurship Unit, 2012.

[9] S. Joensuu, A. Viljamaa, E. Varamäki and E. Tornikoski, "Development of entrepreneurial intention in higher education and the effect of gender - a latent growth curve analysis," Education + Training, vol. 55, no. 8/9, pp. 781-803, 2013.

[10] T.W.Y. Man, T. Lau and K.F. Chan, "The competitiveness of small and medium enterprises a conceptualization with focus on entrepreneurial competencies," Journal of Business Venturing, vol. 17, no. 2, pp. 123-142, 2002.

[11] G. N. Chandler and E. Jansen, "The founder's self-assessed competence and venture performance," Journal of Business Venturing, vol. 7, no. 3, pp. 223-236, 1992.

[12] R. Ferreras-Garcia, A. Hernández-Lara and E. Serradell-López, "Entrepreneurial competences in a higher education business plan course," Education + Training, vol. 61, no.7/8, pp. 850-869, 2019.

[13] I. Ajzen and M. Fishbein, Understanding attitudes and predicting social behavior. Englewood Cliffs/ NJ: Prentice-Hall, 1980.

[14] M. Fishbein and I. Ajzen, Belief, attitude, intention, and behavior: An introduction to theory and research. Reading/MA: Addison-Wesley, 1975.

[15] M.S. Farooq, M. Salam, A. Fayolle, N. Jaafar and K. Ayupp, "Impact of service quality on customer satisfaction in Malaysia airlines: a PLS-SEM approach," Journal of Air Transport Management, vol. 67, no. 1, pp. 169-180, 2018.

[16] M. S. Farooq, "Modelling the significance of social support and entrepreneurial skills for determining entrepreneurial behavior of individuals. A structural equation modelling approach," World Journal of Entrepreneurship, Management and Sustainable Development, vol. 14, no. 3, pp. 242-266, 2018.

[17] M. Crant, "The proactive personality scale as a predictor of entrepreneurial intentions," Journal of Small Business Management, Vol. 34, no. 3, pp. 42-49, 1996.

[18] C. Wang and P. Wong, "Entrepreneurial interest of university students in Singapore," Technovation, vol. 24, no. 2, pp. 161-172, 2004. 
[19] J. Sequeira, S. Mueller and J. McGee, "The influence of social ties and self-efficacy in forming entrepreneurial intentions and motivating nascent behavior," Journal of Developmental Entrepreneurship, vol. 12, no. 3, pp. 275-293, 2007.

[20] J. Kickul, F. Wilson and D. Marlino, "Are misalignments of perceptions and self-efficacy causing gender gaps in entrepreneurial intentions among our nation's teens?," Journal of Small Business and Enterprise Development, vol. 15, no. 2, pp. 321-335, 2008.

[21] L. Kolvereid, "Prediction of employment status choice intentions," Entrepreneurship Theory and Practice, vol. 21, no. 1, pp. 47-57, 1996.

[22] J.C. Nunnally, Psychometric theory. 2nd Edition. NY: McGraw-Hill, 1978.

[23] H. H. Harman, Modern Factor Analysis, 3rd edition. Chicago: University of Chicago Press, 1976.

[24] P.M. Podsakoff and D.Organ, "Self-reports in organizational research: Problems and prospects," Journal of Management, vol. 12, no. 2, pp. 531-544, 1986.

[25] P.M. Podsakoff, S.B. MacKenzie, J-Y. Lee and N.P. Podsakoff, "Common Method Biases in Behavioral Research: A Critical Review of the Literature and Recommended Remedies," Journal of Applied Psychology, vol. 88, no. 5, pp. 879-903, 2003. 


\section{APPENDIX 1.}

\section{Items measuring perceived behavioral control (scale 1-7):}

[1] If I established a business and started to work as an entrepreneur after graduation, my chance of success would be ... very slim - very good

[2] If I really wanted to, I could easily start a business and work as an entrepreneur after graduation. disagree completely - agree completely

[3] There are 1 very few - 7 numerous things that are beyond my own control but could prevent me from starting my own business and working as an entrepreneur after graduation. very few numerous

[4] For me, starting my own business and working as an entrepreneur after graduation would be... very easy - very difficult

[5] If I established my own business and started to work as an entrepreneur after graduation, my risk of failure would be...very small - very big

\section{Items measuring entrepreneurial competence (scale 1-7, disagree completely - agree completely):}

[1] I can use my imagination and abilities to identify opportunities for creating value

[2] I know how to team-up, collaborate and network

[3] I can initiate processes that create value and can take up challenges.

[4] I believe in myself and keep developing.

[5] I can develop creative and purposeful ideas

[6] I have a good understanding of financial and economic issues.

[7] I know how to prioritize, organize and follow-up

[8] I know how to stay focused and don't give up

[9] I can work towards a vision of my future

[10] I can make the most of ideas and opportunities.

[11] I can make decisions, thus dealing with uncertainty, ambiguity and risk.

[12] I can assess the consequences and impact of ideas, opportunities and actions.

[13] I reflect and learn from both success and failure, my own and other people's.

[14] I gather and manage the resources I need

[15] I inspire, enthuse and get others on board. 